Original research article

\title{
The reliability of the Czech version of the Richards-Campbell Sleep Questionnaire
}

\author{
Hana Locihová ${ }^{1,2}{ }^{*}$, Katarína Žiaková ${ }^{1}$, Dagmar Šerková ${ }^{3,4}$, Simona Černochová ${ }^{4}$, Nikola Rajtrová ${ }^{4}$, \\ Vendula Pončíková ${ }^{4}$ \\ ${ }^{1}$ Comenius University in Bratislava, Jesseniuss Faculty of Medicine in Martin, Department of Nursing, Martin, Slovak Republic \\ ${ }^{2}$ AGEL Educational and Research Institute (VAVIA), Prostějov, Czech Republic \\ ${ }^{3}$ University of Ostrava, Faculty of Medicine, Department of Nursing and Midwifery, Ostrava, Czech Republic \\ ${ }^{4}$ Hospital Nový Jičín, Interdisciplinary Intensive Care Unit, Nový Jičín, Czech Republic
}

\begin{abstract}
Background: Sleep disorders are very frequent among all intensive care unit patients, and disturbed sleep quality has clear and straightforward negative consequences for patients' recovery and level of distress. To promote sleep, nurses must have instruments for observing and evaluating patients' sleep.

Objective: The objective of the research was to determine the internal consistency of the Richards-Campbell Sleep Questionnaire (RCSQ) and to compare the selected relationships between the variables (gender, age, type of admission) in the Czech clinical environment of the intensive care unit.

Design: Cross-sectional study.

Methods: The RCSQ has been translated according to the translation and cultural adaptation manual. The quality of sleep was assessed using the Czech version of the RCSQ. The sample consisted of 105 patients hospitalised in an interdisciplinary intensive care unit. The quality of sleep was measured using a visual analogue scale (0-100).

Results: The internal consistency (Cronbach's $\alpha$ ) of the Czech version of the RCSQ is 0.89 . The average RCSQ score in the sample was 53.2 (SD 20.1). Return to sleep was the lowest rated item at 51 (SD 24.2), while sleep quality was the highest rated item at 55.6 (SD 26.4). There was no statistically significant relationship $(p<0.05)$ between sleep quality and selected variables: age $(F=0.1 ; p=0.736)$, gender $(F=0$; $p=0.929)$, type of admission $(F=1.8 ; p=0.183)$.

Conclusions: The study demonstrates that the Czech version of the RCSQ is rated as a reliable tool and can be used to subjectively assess sleep quality in critically ill patients. The association between sleep quality and selected variables has not been statistically proven and its perception is very individual.
\end{abstract}

Keywords: Intensive care unit; Reliability; Richards-Campbell Sleep Questionnaire; Sleep quality

\section{Introduction}

Sleep is one of the basic physiological needs. Sleep disorders are very common in patients in an intensive care unit (ICU) (Parthasarathy and Tobin, 2004). Sleep studies have revealed (Friese, 2008; Weinhouse and Schwab, 2006) that total sleep time over the duration of 24 hours is very often unchanged (6-9 hours), but up to $50 \%$ of this time is patients sleeping during the day. According to sleep-related studies (Cooper et al., 2000; Freedman et al., 2001; Parthasarathy and Tobin, 2004), sleep abnormalities mainly manifest as prolonged sleep latency, significant sleep fragmentation and severe reduction in stage 3, and rapid eye movement sleep. Sleep disorders are associated with a general alteration of the patients' state, with negative biological effects on the organism, which are then manifested in all systems. It affects cardio-respiratory (Leung and Bradley, 2001) with a higher risk of failure of non-invasive ventilation (Roche Campo et al., 2010); metabolic, endocrine and immunological responses (Ganz, 2012; Spiegel et al., 1999), and is also involved in prolonged wound healing (Mostaghimi et al., 2005) and a greater incidence of falls (Wu and Sun, 2017). A Puerto Rican study (Figureoa-Ramos et al., 2009) confirms a higher incidence of delirium that leads to prolonged hospitalisation. The ICU environment is very inhospitable and there are many factors that negatively affect sleep quality in critically ill patients. Factors contributing to sleep disorders in the ICU can be divided into two categories (environmental and non-environmental), and there is a significant causal relationship between them. The non-environmental factors include the patient's underlying disease and physical condition, pain and discomfort, psychosocial factors (stress, anxiety) and medication. The environmental factors comprise noise, light and nursing interventions (Pisani et al.,

\footnotetext{
* Author for correspondence: Hana Locihová, AGEL Educational and Research Institute (VAVIA), Mathonova 291/1, 79604 Prostějov, Czech Republic; e-mail address: H.Reichelova@seznam.cz http://doi.org/10.32725/kont.2019.001

Submitted: 2018-10-20 • Accepted: 2019-01-22 • Prepublished online: 2019-01-30 
2015; Rittayamai et al., 2016; Tembo and Parker, 2009). In order to achieve and maintain a maximum level of sleep quality, effort is made to implement organisational measures - sleep promoting strategies (Elliott and McKinley, 2014; Hu et al, 2015; Norton et al., 2015; Poongkunran et al., 2015). The method of its evaluation in critically ill patients is an important limitation in the evaluation of the effectiveness of these measures. Two basic groups of techniques for evaluating sleep quality are distinguished: objective and subjective. Objective techniques include polysomnography (PSG), actigraphy (ACT), and a method of measuring brain activity using the bispetal index (BIS). Nurses use subjective techniques to determine sleep quality, such as a simple tool which allows its assessment. At present, there are a variety of self-assessment scales and questionnaires focused on quantifying and qualifying sleep quality and sleep disorders as well as on factors which have a significant negative effect on the sleep of ICU patients (Hoey et al., 2014; Jeffs and Darbyshire, 2017; Ritmala-Castren et al., 2016). The Richards-Campbell Sleep Questionnaire (RCSQ) is the most commonly used tool for evaluating subjective sleep quality in ICU. The questionnaire was originally created for critically ill patients and was scientifically validated (Richards et al., 2000). Validity, reliability and internal consistency have been confirmed in several previous studies (Chen et al., 2018; Frisk and Nördstorm, 2013; Nicolás et al., 2008). The RCSQ provides a short, applicable, comprehensive and simple tool to assess sleep quality in ICU and is also the most widespread (Jeffs and Darbyshire, 2017; Ritmala-Castren et al., 2016). The sleep quality assessment tools improve the detection of its disorders. However, their use in clinical practice is not widespread (Hoey et al., 2014; Ritmala-Castren et al., 2016).

\section{Objectives}

The aim of the research was to determine the internal consistency of the RCSQ and to compare the relationships between the selected variables (gender, age, type of admission) in the Czech clinical environment of the intensive care unit.

\section{Materials and methods}

\section{Design \\ Cross-sectional study.}

\section{Sample}

The examined sample consisted of 105 patients hospitalised in the interdisciplinary intensive care unit (IDICU) in hospital Nový Jičín (12 beds, unselected admission of patients). Inclusion criteria were: conscious, alert, score of 15 on the Glasgow Coma Scale (GCS), hospitalised in the ICU for more than 24 hours, over 18 years old, and voluntary consenting to the research. A patient's refusal to participate in the research was considered an exclusion criterion.

\section{Data collection}

The questionnaire technique was used. The distribution of questionnaires and the selection of suitable patients was carried out by four trained nurses. It took approximately 2 to 5 minutes to complete the questionnaire. The research took place from December 2017 to May 2018. To eliminate possible distortions, patients evaluated the previous night's sleep the following day (between 7 am and 9 am in the morning), and always only once during their hospitalisation in the ICU. In the case of patients with visual impairment or another physical handicap, a trained nurse completed the questionnaire with them.

\section{Questionnaire on sleep quality assessment}

Sleep quality assessment in the intensive care unit was measured by a specific standardised Richards-Campbell Sleep Questionnaire (RCSQ), which was designed by Dr. Richards in 2000. The RCSQ contains 5 items which are focused on determining the following items: sleep depth, falling asleep, awakening, return to sleep, and sleep quality + optional noise item (rated separately). Each item is rated using a 0-100 visual analogue scale (VAS). The total score is derived from the sum of the individual items divided by their number. 0 represents the worst sleep, 100 the best sleep. According to Richards (Richards et al., 2000), it is possible to supplement the subjective evaluation based on the formula with the sleep efficiency index [SEI: $46.88+(0.39 \times$ total RCSQ score $)$. An SEI higher than $85 \%$ indicates good sleep quality. The Australian study (McKinley et al., 2013) categorises the answers into three sections: 0-33 (<34): poor sleep, 34-66: satisfactory sleep, 67-100 (>66) good sleep. The following data were collected from demographic data: age and gender from clinical data, mechanical ventilation, length of hospitalisation in the ICU, type of admission, surgery, main diagnosis, and medication (benzodiazepines, antipsychotics and opiates).

\section{Translation process}

The translation and linguistic validation of the questionnaire was carried out according to the translation and cultural adaptation of "Translation and the cultural adaptation of patient - reported outcome (PRO)" of 2005 (Wild et al., 2005). The translation of the questionnaire proceeded in the following steps:

1. Forward translation: translation from the English version into Czech language by two independent professional translators, including the creation of a unified Czech version.

2. Backward translation a backward translation in English, which was compared with the original questionnaire after its completion. Subsequently, he/she commented on the differences between the original and the backward translation and suggested the adaptation of the items in Czech.

3. Expert group: after the translation phase, an expert group consisting of an academic and four nurses met up. The purpose of the meeting was to agree that the proposed final translation was equivalent to the original questionnaire and that the Czech items matched in terms of the content and semantics.

4. Patient testing: the pilot testing was performed in 10 patients at the IDICU in hospital Nový Jičín. The patients included in the pilot test were not included in the final sample.

The process of linguistic validation took 5 weeks.

\section{Ethical aspects}

The research was carried out in accordance with the Declaration of Helsinki. The research was approved by the Ethics Committee of hospital Nový Jičín. The participation in the research was voluntary and the anonymity of respondents was observed. Consent to translate the questionnaire was requested directly from the author. 


\section{Data analysis}

Descriptive statistics was used to analyse demographic clinical data, and to assess the individual items in the questionnaire. Of the methods of descriptive statistics, absolute frequency $(n)$, relative frequency (\%), calculation of the arithmetic mean (mean), and standard deviation (SD) were applied. The statistical analysis of relationships between the RCSQ, gender, age and type of admission was carried out using a model of three-factor analysis of variance at the significance level $p<$ 0.05 .

Before the correlation analysis, the symmetry of the distribution of individual variables was verified using the quantitative-quantile graph for normal distribution. Multidimensional data homogeneity was then verified using Hotelling's $T^{2}$ statistics at $p<0.001$ level, and at this level 2 points were identified as non-homogeneities and excluded from the correlation analysis. Data homogeneity and symmetry were verified by the residue analysis (Meloun et al., 2002; 2004). The estimation of internal consistency was performed using Cronbach's $\alpha$ after pairwise correlation analysis. The correlation analysis and calculation of Cronbach's $\alpha$ were performed using the NCSS 2007 software (Kaysville, UT, USA). Statistical Software Statgraphics Centurion XV Version 12.2.06 from Statpoint, Inc. (Warrenton, VA, USA) was used to analyse the variance and verify data symmetry.

\section{Results}

\section{Demographic and clinical characteristics}

A total of 105 patients met the entry criteria. The sample of patients consisted of 48 men (45.7\%) and 57 women (54.3\%), with the average age 63.2 (SD 14.7). The average length of hospitalisation on the day of completing the questionnaire was 3.31 (SD 1.73). 69 of the planned patients were admitted to the IDICU (65.7\%). 88 patients $(83.8 \%)$ underwent a surgery and 23 respondents (21.9\%) were supported by mechanical ventilation. The most common diagnosis was oncology in 45 respondents $(42.9 \%)$ and 55 patients $(52.4 \%)$ were medicated with opiates (Table 1$)$.

Table 1. Demographic and clinical data $(n=105)$

\begin{tabular}{lcc} 
& $n(\%)$ & Mean \pm SD \\
\hline men & $48(45.7)$ & \\
mechanical ventilation & $23(21.9)$ & \\
operation & $88(83.8)$ \\
elective admission & $69(65.7)$ & \\
urologic diagnosis & $9(8.57)$ & \\
cardiologic diagnosis & $6(5.71)$ & \\
sepsis & $4(3.81)$ & \\
respiratory diagnosis & $3(2.86)$ \\
oncologic diagnosis & $45(42.9)$ & \\
others & $38(36.2)$ & \\
opiates & $55(52.4)$ & \\
benzodiazepines & $8(7.62)$ & $3.31 \pm 1.73$ \\
antipsychotic drugs & $11(10.5)$ & \\
age & & \\
length of hospitalization on & & \\
the day of completion &
\end{tabular}

\section{Richards-Campbell Sleep Questionnaire}

The average RCSQ score of the 105 respondents was 53.2 (SD 20.1). 20 patients (19\%) reported a score of 0-33 (poor sleep), 52 patients (49\%) reported a score of 34-66 (satisfactory sleep) and 33 patients (32\%) reported a score of 67-100 (good sleep). The lowest rated item was 'return to sleep' which scored 51 (SD 24.2), while the highest rated item was 'sleep quality' at 55.6 (SD 26.4). The sleep efficiency index (SEI) was 67.6 (SD 7.84) $<85 \%$, indicating lower sleep quality (McKinley et al., 2013). The optional noise item reached the value of 65.8 (SD 23.2) (Table 2).

\section{Table 2. Richards-Campbell Sleep Questionnaire $(n=105)$}

\begin{tabular}{|c|c|}
\hline Richards-Campbell items & Mean \pm SD \\
\hline sleep depth & $53.4 \pm 24.3$ \\
\hline falling asleep & $53 \pm 24.7$ \\
\hline awakening & $53.1 \pm 20.7$ \\
\hline return to sleep & $51 \pm 24.2$ \\
\hline sleep quality & $55.6 \pm 26.4$ \\
\hline RCSQ total ${ }^{\mathrm{a}}$ & $53.2 \pm 20.1$ \\
\hline noise & $65.8 \pm 23.2$ \\
\hline sleep efficiency index ${ }^{b}$ & $67.6 \pm 7.84$ \\
\hline \multicolumn{2}{|c|}{$\begin{array}{l}\text { a } R C S Q \text { total: mean } 5 \text { items }(\mathrm{Q} 1-\mathrm{Q} 5) / 5 \\
\mathrm{~b} \text { Sleep efficiency index }(\mathrm{SEI})=46.88+\left[0.39^{*} \mathrm{RCSQ} \text { total }\right] \text {; } \mathrm{SEI}>85 \%= \\
\text { good quality of sleep }\end{array}$} \\
\hline
\end{tabular}

The internal consistency of the Czech version of the RCSQ was evaluated in 103 patients (2 patients excluded for data inhomogeneity) and Cronbach's $\alpha=0.89$ (Table 3).

\section{Relationships between variables}

The parameters of gender, age, and type of admission in relation to sleep quality were evaluated in a total of 105 patients. The sample consisted of 48 men $(45.7 \%)$ and 57 women (54.3\%). 47 patients $>65$ years old (44.8\%) and 58 patients $\geq 65$ years old (55.2\%). The admission of the majority of patients was planned (69 patients, $65.7 \%$ ); 36 patients (34.3\%) were emergency cases. There was no statistically significant correlation between gender and sleep quality $(F=0 ; p=0.929)$ or between the type of admission and sleep quality $(F=1.8 ; p=$ 0.183 ). There were also no significant differences in subjective sleep quality assessment among patients up to 65 and above this age limit $(F=0.1 ; p=0.736)($ Chart 1$)$.

\section{Discussion}

In the case of patients hospitalised in intensive care, quality sleep is essential and its disorders adversely affect the whole organism. The impact of homeostatic sleep demand deficiency is a complex problem that not only affects the somatic state of the individual but also interferes with some other levels of the individual; it exacerbates physical deprivation, accentuates experiencing and threatens the balance (Salzmann-Erikson et al., 2016). Drake et al. (2004) state that sleep is a vulnerable state and can be included among "trait factors" manifested by "sleep responsiveness", which the author defines as a specific, predisposing character of an individual to respond to a specific event (illness) by a situational sleep disorder caused by maladaptation (hospitalisation). This finding may have a 
Table 3. Pearson's correlations between components of RCSQ $(n=103 ; p<0.001)$

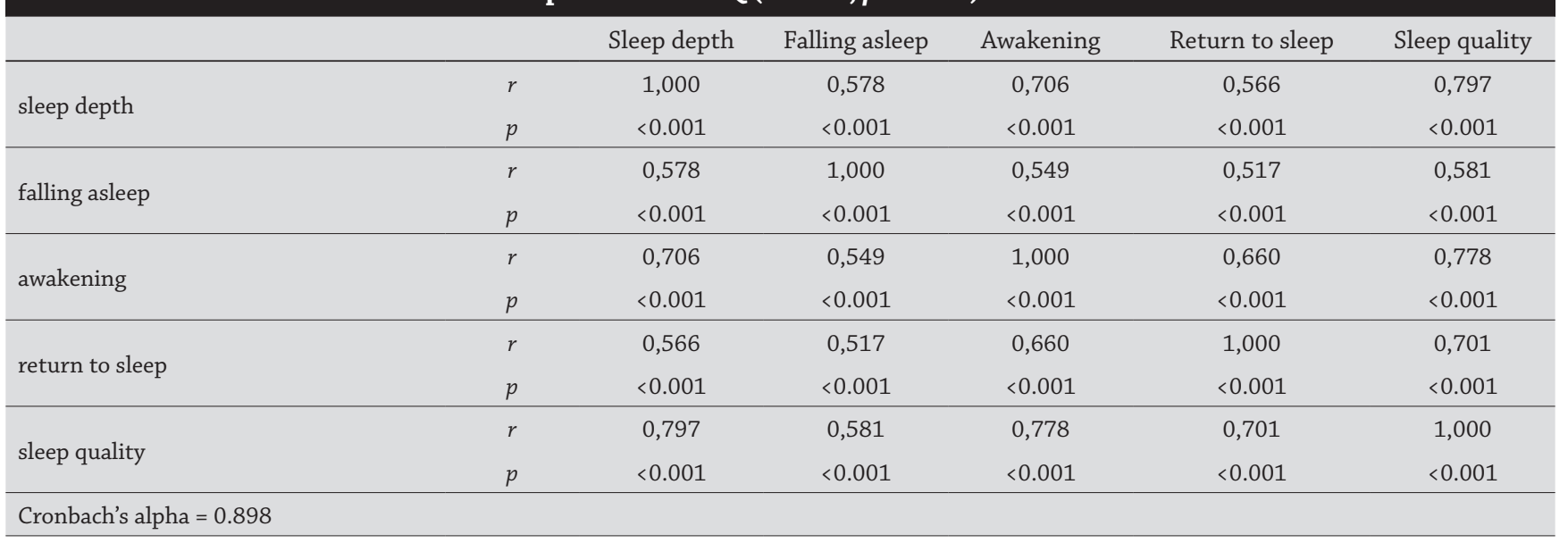

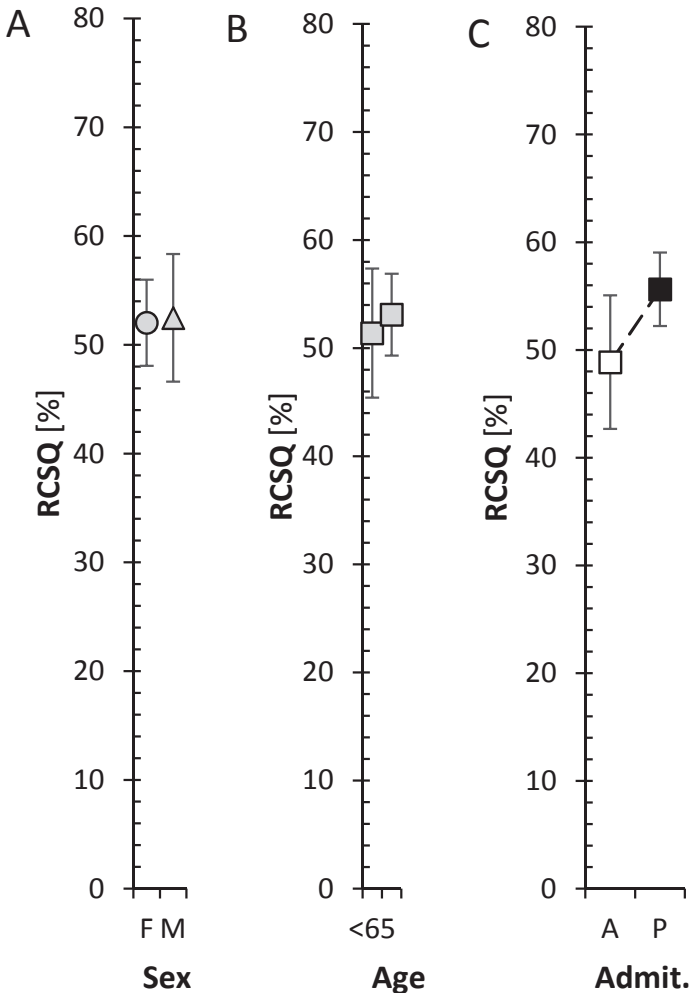

$(n=105 ; p<0.05$; three-way ANOVA model): $\operatorname{Sex}(F=0 ; p=0.929)$ age $(F=0.1 ; p=0.736)$; admit $(F=1.8 ; p=0.183)$

Chart 1. Correlations between variables

profound clinical significance for the nurse who takes care of such a patient. A US study (Ye et al., 2013) states that one of the barriers to improving sleep quality in the case of hospitalised patients is the lack of standardised tools to evaluate and meet this need. If a nurse is to assess the quality of sleep in the case of intensive care patients, she must monitor it using appropriate assessment tools (questionnaires, scales). In the Czech Republic, there has been no tool available for nurses to assess the subjective quality of sleep, and this is perhaps one of the reasons that nurses do not routinely evaluate sleep. RCSQ is a short comprehensive tool for subjective sleep quality assessment in the case of intensive care patients. It is the most extensively used one abroad. Its psychometric proper- ties have been verified by studies: reliability was assessed using Cronbach's $\alpha=0.89-0.92$ (Aitken et al., 2017; Frisk and Nördstorm, 2003; Kamdar et al., 2013; Krotsetis et al., 2017; Li et al., 2011; Menear et al., 2017; Navarro-García et al., 2017; Nicolás et al., 2008; Ritmala-Castren et al., 2017;), the content validation was 0.84 (Chen et al., 2018) and the criterion validity (RCSQ versus polysomnograph) shows correlation $r=$ 0.58 ( $p$ < 0.001) [eigenvalue: 3.61, variance 72.2] (Richards et al., 2000). The reliability of the Czech version of RCSQ evaluated by Cronbach's $\alpha$ was 0.898 . Usually, as the acceptable minimum is stated as $\alpha>0.70$, and the value $0.8 \leq \alpha<0.9$ is therefore interpreted as good (Terwee et al., 2007). We can see that RCSQ is assessed as a reliable tool and can be used for subjective assessment of the sleep quality in the case of critically ill patients in our sociocultural conditions.

When evaluating individual RCSQ items, the lowest rated item was 'return to sleep' (51, SD 24.2), while the highest rated item was 'sleep quality' (55.6, SD 26.4). The study also confirms that subjective sleep quality of the intensive care patients is impaired: a total score of 53.2 (SD 20.1). This is consistent with the available results of foreign works (Aitken et al., 2017; Chen et al., 2018; Frisk and Nördstorm, 2003; Kamdar et al., 2013; Krotsetis et al., 2017; Li et al., 2011; Menear et al., 2017; Navarro-García et al., 2017; Nicolás et al., 2008; Richards et al., 2000; Ritmala-Castren et al., 2017).

Sleep problems of hospitalised patients are very often related to the illness causing their hospitalisation and to the hospital environment. The intensive care environment is very inhospitable (light, noise, nursing interventions). In the theory of Florence Nightingale, the environment is a central concept that the nurse can significantly influence with appropriate nursing interventions. In her conception, she described three levels of relations: patient - environment, nurse - environment, and nurse - patient. There is a new concept arising from the Nightingale model, which is known as "healing environment" (HE). The approach emphasises the "bio-behavioural perspective" in all three levels of relations. The aim of this holistically oriented integrative approach is to eliminate the negative effects of the hospital environment (noise, light, air quality and temperature, patient's comfort) by targeted nursing interventions (Fontaine et al., 2001; Mellot et al., 2008). This concept is further elaborated and integrated in relation to the need for sleep in "sleep promoting strategies" (Elliott and McKinley, 2014; Gardner et al., 2009). The principle of the so-called "sleep promotion strategies" are non-pharmacological nursing interventions. In this strategy, four major domains 
can be identified: noise reduction, reduction of light, clustering of nursing activities and increasing of patient's comfort (Eliassen and Hopstock, 2011). An analysis of available studies indicates that factors inducing sleep disorders can be modified by targeted interventions (Elliott and McKinley, 2014; Poongkunran et al., 2015; Salzmann-Erikson et al., 2016). There is also a growing number of studies demonstrating that the introduction of these organisational changes also reduces significantly the occurrence of delirium (Flannery et al., 2016; Patel et al., 2014). Usage of alternative and complementary techniques can improve the quality of sleep, too. These practices are becoming more important in both the non-professional and professional community, where a particular role also begins to be attributed to them according to the principles of evidence-based practice (EBP). These techniques are appropriate in relation to the sleep of critically ill patients. However, their efficacy is very variable. These techniques originate from the numerous studies that were conducted in Asia (Chen et al., 2012). In the Czech Republic, their application is also difficult due to the lack of experts (no study was conducted that evaluates the benefit of this method in our socio-cultural conditions). Another area of nursing interventions are educational programmes for patients with a focus on adherence to the principles of sleep hygiene, which can be a suitable tool for nursing care. In order for the nurse to be able to educate the patient correctly and comprehensively about the correct principles of sleep hygiene and the negative effects of sleep disorders on the body, it is very important to raise the awareness of the nurses themselves about this need (e.g. an expert seminar on innovative concept of care with the emphasis on sleep need). It can be summarised that the introduction of these sleep-promoting strategies is perceived as a cheap and effective tool to improve sleep quality of hospitalised patients. While the described measures are gradually becoming a common part of everyday nursing practice around the world, in the Czech Republic, this tool - that may potentially improve the quality of care has not yet been implemented in a substantial way.

The correlations between the selected variables (age, gender, type of the admission) in relation to the sleep quality were also evaluated. Age is an important factor that affects both the condition of the patient and sleep quality. In our study, a statistically significant difference in age-related sleep quality was not confirmed $(F=0.1 ; p=0.736)$. The impact of age was evaluated in the studies of the authors (Matsumoto et al., 2015; Sterniczuk et al., 2014), who, on the basis of the results, suggest that stages of sleep change in people aged 60 years and more, and there is a higher incidence of sleep-related respiratory disorders and abnormal movements related to sleep, and subjectively impaired sleep quality. The sociological analysis sought to examine the relationship between sleep quality perception in patients in ICU from the gender perspective. This correlation was not found to be statistically significant in our work (despite the initial theoretical assumptions) $(F=0 ; p=$ 0.929). Despite the fact that our results did not confirm a statistically significant relationship, most studies agree that emotional and cognitive processes are significantly affected by gender (Bem, 1974; Formánková, 2009) and can affect patients both at the physical level (sleep) and mental level (loss of motivation, resignation to the situation). The intensive care environment has its own specifics and differences that predestine its character and can be significantly stressful for the patient. Emergency admission can be one of the attributes that can significantly affect this stressful situation and thus contribute to sleep disorders. Although study outcomes provide evidence (Buter and Koopmans, 2015; Hofhuis et al., 2003) that the emergency patients (in comparison with electives) are signifi- cantly older and their health issues are more severe (APACHE score), it is also biochemically proven that these patients have a significantly reduced level of glutamine, which may negatively influence the clinical results, and based on these findings, worse sleep quality may occur. Our statistical analysis, however, did not confirm significant interdependency between the type of admission and its quality $(F=1.8 ; p=0.183)$.

\section{Implication for practice}

1. Sleep disorders are very frequent among all intensive care unit patients (compared to the general ward patient population).

2. Sleep deprivation and disturbed sleep quality have clear and straightforward consequences for a patient's level of distress.

3. Use of the tools to assess sleep and its quality is neglected by nurses.

4. The Czech version of the RCSQ is a reliable tool for assessing sleep quality in ICU.

5. Subjective sleep quality of patients in ICU is very individual.

6. Interventions improving the quality of sleep could affect the global critical care outcome of intensive care unit survivors and should be a part of good quality clinical practice in the future.

\section{Limitations of the study and recommendations}

The unicentric nature of the study is its limitation. The selection of the sample according to the identified criteria, which can distort the results, is another limitation. Further research could be focused on inter-rater reliability (nurse cf. patient) when assessing sleep quality using the Czech version of the RCSQ.

\section{Conclusions}

Lack of adequate quality sleep and length in an intensive care unit is a significant negative factor affecting the quality of provided care. In many respects, it is rather challenging to satisfy one's need for sleep; mainly due to difficulties in sleep quality assessment. Based on the data obtained from our study, the Czech version of the Richards-Campbell Sleep Questionnaire provides a short, applicable, comprehensive and simple tool with proven reliability to assess sleep quality and is a useful tool for clinical practice. The association between sleep quality and selected variables (age, gender, type of admission) has not been statistically proven and its perception is very individual. However, at present, expert publications agree on the importance of the use of non-pharmacological strategies for inducing sleep in intensive care units.

\section{Ethical aspects and conflicts of interest}

The authors declare that there is no conflict of interest regarding the surveillance study and that the ethical aspects were respected while processing the results. All the used bibliographical sources were properly cited.

\section{Acknowledgements}

Our study had no external funding source.

\section{Authors' contributions}

Concept and design (HL), data collection (DŠ, SČ, NR, VP), manuscript draft (HL), critical revision of the manuscript (DŠ), final approval of the manuscript (KŽ). 


\section{Reliabilita české verze Richards-Campbell Sleep dotazníku}

\section{Souhrn}

Cíl: Cílem výzkumu bylo určit míru vnitřní konzistence Richards-Campbell Sleep Questionnaire (RCSQ) a porovnat vytipované vztahy mezi proměnnými (pohlaví, věk, druh přijetí) v českém klinickém prostředí jednotky intenzivní péče.

Design: průřezová studie.

Metodika: RCSQ byl přeložen podle manuálu pro překlad a kulturní adaptaci. Hodnocení kvality spánku bylo zjištováno pomocí české verze RCSQ. Soubor tvořilo 105 pacientů hospitalizovaných na mezioborové jednotce intenzivní péče. Hodnocení kvality spánku bylo měřeno pomocí vizuální analogové škály (0-100).

Výsledky: Průměrné skóre RCSQ v souboru bylo 53.2 (SD 20.1). Nejníže hodnocenou položkou bylo opětovné usínání po probuzení - 51 (SD 24.2), naopak nejlépe hodnocenou položkou byla kvalita spánku - 55.6 (SD 26.4). Vnitřní konzistence (Cronbachova $\alpha$ ) české verze RCSQ je 0.89. Nebyl potvrzen statisticky signifikantní vztah $(p<0.05)$ mezi kvalitou spánku a vytipovanými proměnnými: věk $(F=0.1, p=0.736)$, pohlaví $(F=0, p=0.929)$, druh přijetí $(F=1.8, p=0.183)$.

Závěr: Studie demonstruje, že RCSQ v české verzi je hodnocen jako spolehlivý nástroj a může být použíán k subjektivnímu hodnocení kvality spánku u kriticky nemocných. Asociace mezi kvalitou spánku a vytipovanými proměnnými nebyla statisticky prokázaná a jeho vnímání je velmi individuální.

Klíčová slova: Jednotka intenzivní péče; Kvalita spánku, reliabilita; Richards-Campbell Sleep dotazník

\section{References}

1. Aitken LM, Elliott R, Mitchell M, Davis C, Macfarlane B, Ullman A, et al. (2017). Sleep assessment by patients and nurses in the intensive care. Austr Crit Care 30(2): 59-66. DOI: 10.1016/j.aucc.2016.04.001.

2. Bem SL (1974). The measurement of psychological androgyny. J Consult Clin Psychol 42(2): 155-162.

3. Buter H, Koopmans M (2015). Plasma glutamine after acute or elective admission on the ICU. Crit Care 19(Suppl. 1): P402. DOI: $10.1186 / \mathrm{cc} 14482$.

4. Chen JH, Chao YH, Lu SF, Shiung TF, Chao YF (2012). The effectiveness of valerian acupressure on the sleep of ICU patients: A randomized clinical trial. Int J Nurs Stud 49(8): 913-920. DOI: 10.1016/j.ijnurstu.2012.02.012.

5. Chen LX, Ji DH, Zhang F, Li JH, Cui L, Bai CJ, et al. (2018). Richards-Campbell sleep questionnaire: psychometric properties of Chinese critically ill patients. Nurs Crit Care [Epub ahead of print]. DOI: 10.1111/nicc.12357.

6. Cooper AB, Thornley KS, Young GB, Slutsky AS, Stewart TE, Hanly PJ (2000). Sleep in critically ill patients requiring mechanical ventilation. Chest 117(3): 809-818. DOI: 10.1378/ chest.117.3.809.

7. Drake $\mathrm{CH}$, Richardson G, Roehrs T, Scofield H, Roth T (2004). Vulnerability to stress-related sleep disturbance and hyperarousal. Sleep 27(2): 285-291.

8. Eliassen KM, Hopstock LA (2011). Sleep promotion in the ICU a survey of nurses interventions. Intensive Cril Care Nurs 27(3): 138-142. DOI: 10.1016/j.iccn.2011.03.001.

9. Elliott RM, McKinley S (2014). The development of a clinical practice guideline to improve sleep in intensive care patients: A solution focused approach. Intensive Crit Care Nurs 30(5): 246-256. DOI: 10.1016/j.iccn.2014.04.003.

10. Figureoa-Ramos MI, Arroyo-Novoa CM, Lee KA, Padilla G, Puntillo KA (2009). Sleep and delirium in ICU patients: a review of mechanisms and manifestations. Intensive Care Med 35(5): 781-795. DOI: 10.1007/s00134-009-1397-4.

11. Flannery AH, Oyler DH, Weinhouse GL (2016). The impact of interventions to improve sleep on delirium in the ICU: A systematic review and research framework. Crit Care Med 44(12): 2231-2240. DOI: 10.1097/CCM.0000000000001952.

12. Fontaine DK, Prinkey BL, Pope-Smith B (2001). Designing humanistic critical care environments. Critical Care Nurs $Q$ 24(3): 21-34.

13. Formánková L (2009). Zábrodská K: Variace na gender. Poststrukturalismus, diskursivní analýza a genderová identita. Gender, rovné př́ležitosti, výzkum 10(2): 76-78.
14. Freedman NS, Gazendam J, Levan L, Pack AI, Schwab RJ (2001). Abnormal sleep/wake cycles and the effect of environmental noise on sleep disruption in the intensive care unit. Am J Respir Crit Care Med 163(2): 451-457. DOI: 10.1164/ajrccm.163.2.9912128.

15. Friese RS (2008). Sleep and recovery from critical illness and injury: A review of theory, current practice, and future directions. Crit Care Med 36(3): 697-705. DOI: 10.1097/ CCM.0B013E3181643F29.

16. Frisk, U, Nördstorm G (2003). Patients' sleep in an intensive care unit-patients' and nurses' perception. Intensive Crit Care Nurs 19(6): 342-349. DOI: 10.1016/S0964-3397(03)00076-4.

17. Ganz FD (2012). Sleep and immune function. Crit Care Nurs 32(2): 19-24. DOI: $10.4037 / \mathrm{ccn} 2012689$.

18. Gardner G, Collins C, Osborne S, Henderson A, Eastwood M (2009). Creating a therapeutic environment: A non randomised controlled trial of a quiet time intervention for patients in acute care. Int J Nurs Stud 46(6): 778-786. DOI: 10.1016/j.ijnurstu.2008.12.009.

19. Hoey LM, Fulbrook P, Douglas JA (2014). Sleep assessment of hospitalised patients: a literature review. Int J Nurs Stud 51(9): 1281-1288. DOI: 10.1016/j.ijnurstu.2014.02.001.

20. Hofhuis J, Hautvast JLA, Schrijvers AJP, Bakker J (2003). Quality of life on admission to the intensive care: can we query the relatives? Intensive Care Med 29(6): 974-979. DOI: $10.1007 / \mathrm{s} 00134-003-1763-6$.

21. Hu RF, Jiang XY, Chen J, Zeng Z, Chen XY, Li Y, et al. (2015). Non-pharamacological interventions for sleep promotion in the intensive care unit. Cochrane Database Syst Rev (10): CD008808. DOI: 10.1002/14651858.CD008808.pub2.

22. Jeffs EL, Darbyshire JL (2017). Measuring sleep in the intensive care unit: a critical appraisal of the use of subjective methods. J Intensive Care Med 1: 885066617712197. DOI: 10.1177/0885066617712197.

23. Kamdar BB, King LM, Collop NA, Sakamuri S, Colantuoni E, Neufeld KJ (2013). The effect of a quality improvement intervention on perceived sleep quality and cognition in a medical ICU. Crit Care Med 41(2): 800-809. DOI: 10.1097/ CCM.0b013e3182746442.

24. Krotsetis S, Richards KC, Behncke A, Köpke S (2017). The reliability of the German version of the Richards Campbell Sleep Questionnaire. Nursing Crit Care 22(4): 247-252. DOI: $10.1111 /$ nicc.12275.

25. Leung RS, Bradley TD (2001). Sleep apnea and cardiovacular disease. Am J Respir Crit Care Med 164(12): 2147-2165. DOI: 10.1164/ajrccm.164.12.2107045.

26. Li SY, Wang TJ, Wu SF, Liang SY, Tung HH (2011). Efficacy of controlling night-time noise and activities to improve patients 
sleep quality in a surgical intensive care unit. J Clin Nurs 20(3-4): 396-407. DOI: 10.1111/j.1365-2702.2010.03507.x.

27. Matsumoto M, Sugama J, Nemoto T, Kurita T, Matsuo J, Dai M, et al. (2015). The nature of sleep in 10 bedridden elderly patients with disorders of consciousness in a Japanese hospital. Biol Res Nurs 17(1): 13-20. DOI: 10.1177/1099800414523118.

28. McKinley S, Fien M, Elliott R, Elliott D (2013). Sleep during and after critical illness and psychological health in recovery. Aust Crit Care 26(2): 83-101. DOI: 10.1016/j.aucc.2013.02.008.

29. Mellot KG, Sharp PB, Anderson LM (2008). Biobehavioral measures in a critical - care healing environment. J Holist Nurs 26(2): 128-135. DOI: 10.1177/0898010107306690.

30. Meloun M, Hill M, Militký J, Vrbíková J, Stanická S, Skrha S (2004). New methodology of influential point detection in regression model building for the prediction of metabolic clearance rate of glucose. Clin Chem Lab Med 42(3): 311-322. DOI: 10.1515/CCLM.2004.057.

31. Meloun M, Militký J, Hill M, Brereton RG (2002). Crucial problems in regression modelling and their solutions. Analyst 127(4): 433-450. DOI: 10.1039/B110779H.

32. Menear A, Elliott R, Aitken LM, Lal S, McKinley S (2017). Repeated sleep quality assessment and use of sleep-promoting interventions in ICU. Nurs Crit Care 22(6): 348-354. DOI: $10.1111 /$ nicc. 12315

33. Mostaghimi L, Obermeyer WH, Ballamudi B, MartinezGonzalez D, Benca RM (2005). Effects of sleep deprivation on wound healing. J Sleep Res 14(3): 213-219. DOI: 10.1111/j.1365-2869.2005.00455.x.

34. Navarro-García MÁ, de Carlos Alegre V, Martinez-Oroz A, Irigoyen-Aristorena MI, Elizondo-Sotro A, IndurainFernández S, et al. (2017). Quality of sleep in patients undergoing cardiac surgery during the postoperative period in intesive care. Enferm Intensiva 28(3): 114-124. DOI: 10.1016/j. enfi.2016.10.005.

35. Nicolás A, Aizpitarte E, Iruarrizaga A, Vázquez M, Margall A, Asiain C (2008). Perception of night-time sleep by surgical patients in an intensive care unit. Nurs Crit Care 13(1): 25-33. DOI: 10.1111/j.1478-5153.2007.00255.x.

36. Norton C, Flood D, Brittin A, Miles J (2015). Improving sleep for patients in acute hospitals. Nurs Stand 29(28): 396-407. DOI: $10.7748 / \mathrm{ns} .29 .28 .35 . e 8947$.

37. Parthasarathy S, Tobin MJ (2004). Sleep in the intensive care unit. Intensive Care Med 30(2): 197-206. DOI: 10.1007/ s00134-003-2030-6.

38. Patel J, Baldwin J, Bunting P, Laha S (2014). The effect of a multicomponent multidisciplinary bundle of interventions on sleep and delirium in medical and surgical intensive care patients. Anaesthesia 69(6): 540-549. DOI: 10.1111/ anae.12638.

39. Pisani MA, Friese RS, Gehlbach BK, Schwab RJ, Weinhouse GL, Jones SF (2015). Sleep in the intensive care unit. Am J Respir Crit Care Med 191(7): 731-738. DOI: 10.1164/rccm.2014112099CI.

40. Poongkunran C, John SG, Kannan AS, Shetty S, Bime Ch, Parthasarathy S (2015). A meta-analysis of sleep-promoting interventions during critical illness. Am J Med 128(10): 1126-1137. DOI: 10.1016/j.amjmed.2015.05.026.

41. Richards KC, O'Sullivan PS, Philips RL (2000). Measurement of sleep in critically ill patients. J Nurs Meas 8(2): 131-144.

42. Ritmala-Castren M, Axelin A, Kiljunen K, Sainio C, LeinoKilpi H (2017). Sleep in the intensive care unit - nurses' documentation and patients' perspectives. Nurs Crit Care 22(4): 238-246. DOI: 10.1111/nicc.12102.

43. Ritmala-Castren M, Virtanen I, Vahlberg T, Leivo S, Kaukonen KM, Leino-Kilpi H (2016). Evaluation of patients' sleep by nurses in an ICU. J Clin Nurs 25(11-12): 1606-1613. DOI: $10.1111 /$ jocn.13148.

44. Rittayamai N, Wilcox E, Drouot X, Mehta S, Goffi A, Brochard L (2016). Positive and negative effects of mechanical ventilation on sleep in the ICU: a review with clinical recommendations. Intensive Care Med 42(4): 531-541. DOI: 10.1007/s00134-0154179-1.

45. Roche Campo F, Drouot X, Thille AW, Galia F, Cabello B, d'Ortho MP, Brochard L (2010). Poor sleep quality is associated with late noninvasive ventilation failure in patients with acute hypercapnic respiratory failure. Crit Care Med 38(2): 477-485. DOI: 10.1097/CCM.0b013e3181bc8243.

46. Salzmann-Erikson M, Lagerqvist L, Pousette S (2016). Keep calm and have a good night: nurses' strategies to promote inpatients' sleep in the hospital environment. Scand J Caring Sci 30(2): 356-364. DOI: 10.1111/scs.12255.

47. Spiegel K, Leproult R, Van Cauter E (1999). Impact of sleep debt on metabolic and endocrine function. Lancet 354(9188): 1435-1439. DOI: 10.1016/S0140-6736(99)01376-8.

48. Sterniczuk R, Rusak B, Rockwood K (2014). Sleep disturbance in older ICU patients. Clin Interv Aging 9: 969-977. DOI: $10.2147 /$ CIA.S59927.

49. Tembo A, Parker V (2009). Factors that impact on sleep in intensive care patients. Intensive Crit Care Nurs 25(6): 314-322. DOI: 10.1016/j.iccn.2009.07.002.

50. Terwee CB, Bot SD, de Boer MR, van der Windt DA, Knol DL, Dekker J, et al. (2007). Quality criteria were proposed for measurement properties of health status questionnaires. J Clin Epidemiol 60(1): 34-42. DOI: 10.1016/j.jclinepi.2006.03.012.

51. Weinhouse GL, Schwab RJ (2006). Sleep in the critically ill patient. Sleep 29(5): 707-716.

52. Wild D, Grove A, Martin M, Eremenco S, McElroy S, VerjeeLorenz A, et al. (2005). Principles of good practice for the translation and cultural adaptation process for patient-reported outcomes (PRO) measures: report of the ISPOR task force for translation and cultural adaptation. Value Health 8(2): 94-104. DOI: $10.1111 / j .1524-4733.2005 .04054 . x$.

53. Wu L, Sun D (2017). Sleep duration and falls: a systematic review and meta-analysis of observational studies. J Sleep Res 26(3): 293-301. DOI: 10.1111/jsr.12505.

54. Ye L, Keane K, Hutton Johnson S, Dykes PC (2013). How do clinicians assess, communicate about and manage patient sleep in the hospital? J Nurs Admin 43(6): 342-347. DOI: 10.1097/ NNA.0b013e3182942c8a. 